\title{
Covid-19: Portrait of Preservation of the Batik Industry as a Regional Autonomy
}

\author{
Itoimiham Noburu ${ }^{1}$, Arzo Himki $^{2}$, Arusyi Dithi ${ }^{3}$, Katoyusyi Kano ${ }^{4}$, Mey Anggraeni ${ }^{5}$ \\ University Ryukyu, Panjab University, University of Pune, Gifu University, Raharja \\ University \\ e-mail: itoimihamnoburu@gmail.com ${ }^{1}$,arzohimki@yahoo.com², arusyidithi@yahoo.com ${ }^{3}$, \\ katoyusyikano@yahoo.com ${ }^{4}$,mey.anggraeni@raharja.info ${ }^{5}$
}

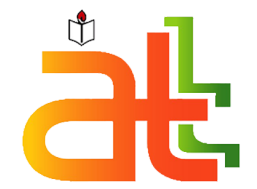

Noburu, I., Himki, A., Dithi, A., Kano, K., \& Anggraeni, M. (2020). Covid-19: Portrait of
Preservation of the Batik Industry as a Regional Autonomy. Aptisi Transactions on
Technopreneurship (ATT), 2(2), 143-152.

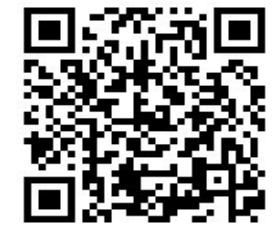

DOI : https://doi.org/10.34306/att.v2i2.91

Author Notifications

In 2020 coronavirus (covid-19) has shocked the world. This virus attacks the immunity of a person's body and the spread of this virus is very fast. The weakening of the Chinese economy due to the co-19 epidemic certainly had a significant impact on the world, because China is a country that is very influential in the world economy. Many various countries were affected by co-19, including Indonesia. This co-19 outbreak is one of the causes of the decline in people's economic capacity. Many companies suffered losses due to the impact of the covid-19 outbreak, the impact experienced one of them in the field of creative industries, many industries had to close because they were affected by the covid-19. One example of industries that are affected by covid-19 is the batik industry typical of Sumenep. In addition to industry, the tourism sector was affected, many tourist sites were closed due to the co-19 impact which did not allow the public to gather in many crowds. The government has made several efforts to reduce the spread of this epidemic by implementing Large-Scale Social Restrictions or commonly called PSBB in almost all areas according to government regulations. The research method used in this study is to use a qualitative perspective method where this research was conducted with the aim of developing and improving Sumenep batik craftsmen during the covid-19 pandemic. The government has made several efforts to reduce the spread of this epidemic by implementing Large-Scale Social Restrictions or commonly called PSBB in almost all areas according to government regulations. The research method used in this study is to use a qualitative perspective method where this research was conducted with the aim of developing and improving Sumenep batik craftsmen during the covid-19 pandemic. The government has made several efforts to reduce the spread of this epidemic by implementing Large-Scale Social Restrictions or commonly called PSBB in almost all areas according to government regulations. The research method used in this study is to use a qualitative perspective method where this research was conducted with the aim of developing and improving Sumenep batik craftsmen during the covid-19 pandemic.

Keywords: Batik Crafts, Sumenep, Economy, Covid-19 


\section{Introduction}

Cultural heritage of the ancestors, namely batik. The diversity of Sumenep Regency in addition to its tourist sites is to have art works. The work of art is a nation's culture that is priceless. Artwork is a culture of society which means noble, meaning that art is very closely related to indigenous culture - istiadat [1]. Batik is a fabric with a pattern that is made from 'wax' (wax) drawn on the fabric, so it is able to hold the incoming coloring material. Batik is an Indonesian culture that must be preserved.

Batik craft is not only recognized in Indonesia, but is recognized by the International because it has unique patterns and patterns and affirmation of its history [2]. In ancient times, the art of batik was only known in the kingdom of Indonesia alone, over time many of the closest people who followed and subsequently many women who made batik crafts into work in their spare time. As time goes by and the development of an increasingly modern era, batik crafts are not only painted on cloth, but have been modified into clothing in all circles. Even today batik is well known abroad.

Java area, is the first area to develop batik crafts, but now batik crafts have expanded to foreign countries. Even so, the most popular batik craft in the world, namely batik originating from Indonesia, especially Java. The determination of batik as a traditional Indonesian cultural heritage was established by UNESCO in October 2009. Recognition of batik is given because the Government and the people of Indonesia have preserved and developed Indonesian culture, especially batik for generations. Batik craft has been felt by all communities and has become a means and infrastructure for lifting dignity and dignity [3]. Before being designated by UNESCO as a traditional Indonesian culture, in 2008 there was a debate with Malaysia about the claim of batik crafts and has gone through a fairly long process of debate over the recognition of batik by the Malaysian state [4]. Since that time the Indonesian government immediately acted with the claim of batik culture by the Indonesian state.

In September 2008 batik craft was officially registered with UNESCO by the Government of Indonesia. Batik was officially recognized by UNESCO as an international cultural heritage in October 2009. According to UNESCO, batik crafts can be developed more than clothing. That the use of batik, users feel they have a culture, nationalism spirit and contribute to preserving the culture of batik crafts. Batik is a piece of cloth that is traditionally made and mainly also used in traditional dimensions, has a variety of decorative patterns and certain patterns that are made using a dye technique with batik wax or called night as a color barrier material.

Specifically, it will explain the protection of traditional culture with copyright and the laws governing the protection of traditional culture. It is listed in Law No. 28 of 2014 article 39, states that copyright in traditional culture is fully held by the State. The state is obliged to protect, preserve and develop traditional culture. In Law No. 5 of 2017 article 5 also provides protection against traditional culture, such as arts, customs and traditional crafts. In article 30 , it states that the development of legal protection of traditional culture which if done well will get legal protection will be able to optimize the quality of life of the people especially indigenous peoples [5].

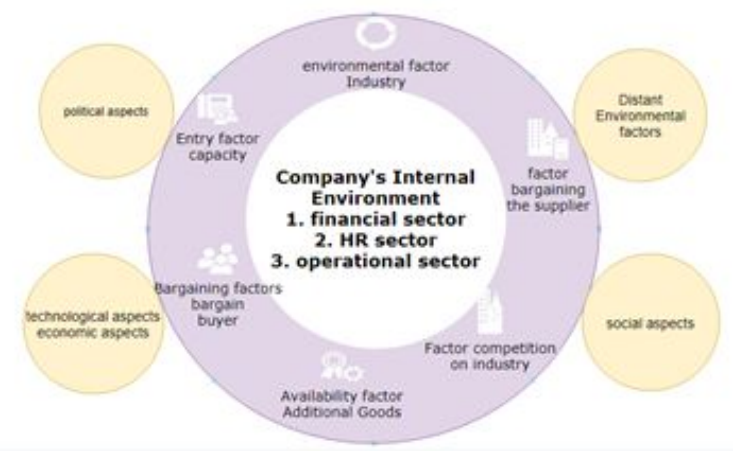


Figure 1. Aspects of the Company's Internal and External Environments

In Sumenep Regency the development of batik crafts is very vulnerable, because there is no one who intends to preserve batik crafts [6]. Not only that, the Government of Sumenep has not fully supported the development of batik crafts. In contrast to the Bangkalan area, many young people participated in preserving batik crafts [7]. That way, the process of designing and creating batik follows market interest. Due to the vulnerability of batik craftsmen, this has reduced the number of batik artists and researchers in Sumenep [8].

The development of Sumenep batik handicrafts underwent many changes that were originally colored batik using natural colors, because in this era of natural coloring has begun hard to come by, so the craftsmen replace batik coloring using chemical colors to make it faster in good manufacturing. At that time the Department of Industry and Trade had opened a batik course for the people of Sumenep. But the government program did not run as expected because the role of the government was very lacking, while the role of the government was needed to motivate the people of Sumenep to make batik crafts, because batik is a traditional culture that must be preserved [9].

\section{Research Method}

\subsection{Research Method}

The research method used in this observation is using descriptive qualitative analysis. That describes the events that occurred during Covid-19 of the world economy. Judging from the recent months, there has been an overall economic downturn in the business sector, both from the tourism sector and the clothing sector. Various strategies that have been carried out by the Government of Indonesia in preventing economic conditions caused by covid-19, but the strategies implemented have not yet been fully in line with expectations [16].

The disruption of the arrival of new members illustrates the economic quality and separation of production in an industry, and competition like this makes it harder for new members to join the industry. For this reason, when there is a disruption in an industry, competition in the industry automatically decreases with time. The Deming Wheel concept, which describes a technique in an industry formed in 4 (four) elements, namely researching the market, product patterns, production systems and product sales. The four elements are bound together in realizing the Deming Wheel Concept in industrial engineering in the new era as it is today.

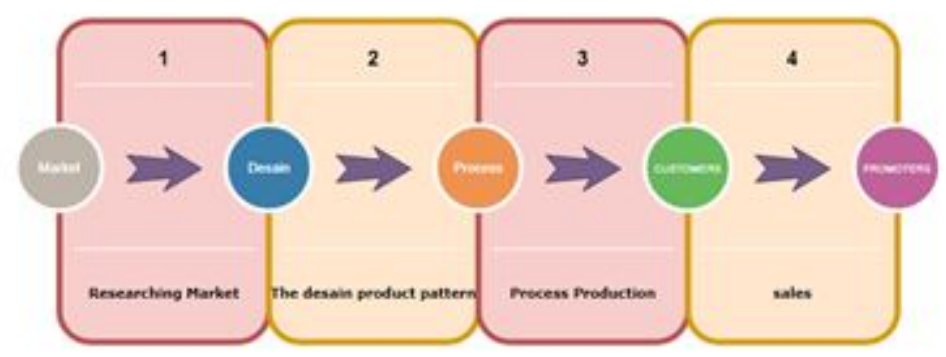

Figure 2. Modern Industrial System Design 
Regarding Figure 2, it explains 4 (four) elements of activity in industrial engineering in the new era now, namely researching the market, designing product patterns, production process systems and sales processes. According to reports on market will obtained from overall observations, the pattern of products is commensurate with market will. The Production Division is required to follow a predetermined form of product design. And the production division is required to develop product capacity, so that product capacity can be proportional to the pattern set by market will with a budget as selective as possible. This can be achieved by destroying the final output of waste during the production system. Related to whether the Indonesian economy can be stable or not? Of course we have to look at many aspects until when this epidemic ends soon.

\subsection{Literature Review}

Regarding literature review, the author discusses in the form of observation to be in line with the theme of observation. At the beginning of the year, the whole world was shocked by the Coronavirus (Covid-19) outbreak that began in China. The Covid-19 virus is a type of MERS and SARS flu that attacks the respiratory tract. Various countries have made efforts to reduce transmission of the virus from quarantine itself to large-scale social restrictions or often called PSBB. With the existence of PSBB, almost all companies and industries are prohibited from operating, for quite a long time and causing a lot of losses to the economy [10]. When this epidemic spreads, a person's immune system becomes a problem, and every time someone outbreaks this outbreak is alienated by the nearest community or the outside environment. This outbreak besides attacking the immune system also attacks the country's economy. The state suffered a very drastic loss, especially from taxes. The surge in losses due to having to deal with emergencies, the deployment of officials and health workers. However, the loss can be compensated for tax and non-tax revenue, so that the country does not lose, unless there is theft or corruption in the implementation of the national loss will be transmitted to the loss of citizens [11]. Because the transmission of this virus is very fast, WHO (World Health Organization) confirmed covid-19 as a pandemic or outbreak. Due to the number of drastic increases in a short period of time, the government implemented an independent lockdown or quarantine system as long as there was a Covid-19 outbreak in accordance with the provisions of Law Number 6 Year 2018 on "Health Quarantine", ie limiting activities or restrictions on someone who has a history of infectious diseases. The current economic improvement refers to the global mobility of anti-capitalism which then demands the development of the micro sector between producers and consumers whose benefits can provide justice and social independence. Not yet finished discussing the economic impact in Indonesia, even lately the world was shocked by the arrival of a new virus called Coronavirus or covid- 19 . This virus seems to have many negative impacts in various sectors [12]. Given the Sumenep area which has a very effective economic capability, both in batik crafts and in terms of tourism which is hampered by the covid-19 outbreak. "Regional Autonomy (Decentralization) created for the prosperity of the community, community independence and improving the administration and economic development of the community [13] regions in order to improve people's welfare. The main objective of regional autonomy is to improve public services and to promote regional economic growth factors. Economic growth is one of the most important indexes to determine the extent of community economic activity in a certain period [14]. "Strategy Marketing and Development of Trusmi Batik in Cirebon District Using Natural Coloring with Qualitative Methods - SWOT Analysis. Natural coloring is very fast, but it has a high selling price value [15].

\section{Results and Analysis}


The creative industry is an industry that utilizes creativity, expertise and the ability to create employment in order to produce creativity of individual creativity. The economy is a method relating to human activities in producing, promoting, trading and using goods or services produced. The economic development towards industry is a form of dream hope in supporting the Master Plan for the Acceleration and Expansion of Indonesian Economic Development (MP3EI) to create the vision and mission of the Indonesian state to be a developed country [17].

In general, small industries have characteristics in weak networks, both horizontal and vertical. This is caused by not having adequate social conditions, for example the lack of good and correct communication. Social capital is capital that has not been paid attention to. So with this, the use of social capital as an important aspect to improve work effectiveness [18].

Industrial economics is a macro economy that discusses the involvement between forms and industry, industry is a union of companies that market products". The industry occurs in a group of companies in order to produce objects that are simple to understand.

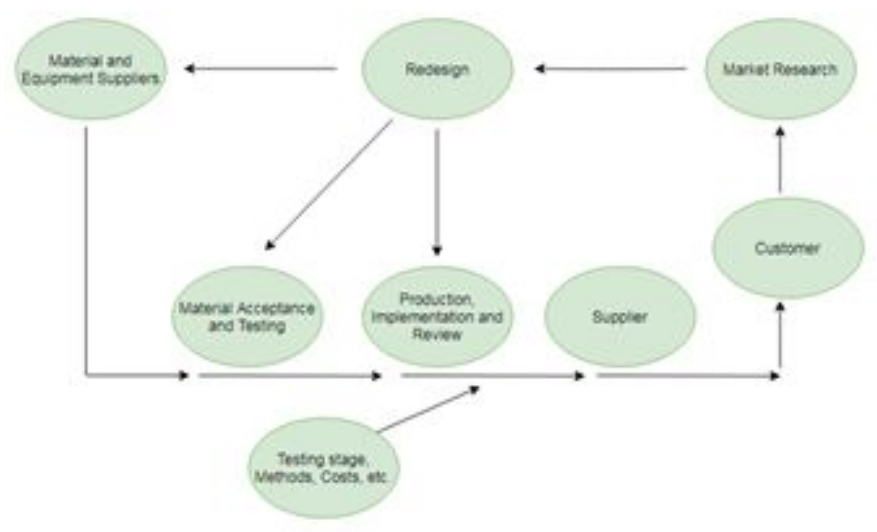

Figure 3. Industrial System Processes

In 2018, the Ministry of Rural Areas made a program called the Regional Product Superior Program or also called the Prukades which aims to develop and develop the rural economy, and focus the government in creating the ideals of regional autonomy. Prukades is made to expand the economy which is focused on one village product that is carried out in cooperation between villages and village-owned companies (PDTT Minister of Rural Regulation No. 19 of 2017 which regulates the Priority of Using Village Funds). One of the regions implementing the Prukades is Sumenep Regency by producing Batik handicrafts typical of Sumenep [19]. In 2005, Gaspersz argued that production was the key in every industry association that had an obligation to publish products that represented each industry. Thus, it can be explained that the concept of production is a concept that explains some of the actions to publish designs in the form of goods and services with changes in input to output. Activity is a process of action that requires more than one input. Inputs here apply to HR (labor), facilities and raw material purchases.

In general, Sumenep batik artisans do not take into account the costs of the production process in detail and do not set the selling price to the market price, so the benefits cannot be known. High competition causes changes in product prices to the number of sales. For this reason, product selling prices are an important factor that must be considered. However, the problem due to high competition is that entrepreneurs choose to 
sell at the same price as their competitors. One way to calculate it can be to use the Gross Domestic Product (GDP) reference, which is the total accumulation of production in a country.

GDP in Indonesia in 2019 to the Central Statistics Agency (BPS) is around 59.1 million. With a population of 267 million people, Indonesia's GDP in 2019 is Rp.15833.9 Trillion (www.bpd.go.id). The proportion of regions in GDP or known as Gross Regional Revenue (GRDP) refers to previous BPS data, namely DKI Jakarta at $17.53 \%$, Bodetabek (Bogor, Depok, Tangerang and Bekasi) at 7.3\%. Indonesia's economic growth in 2020 is estimated at $5.3 \%$, but this figure is corrected as a result of the Covid-19 pandemic and some predict growth below $2 \%$. So the economic losses due to the Covid-19 outbreak in Jabodetabek amounted to $70 \%$ [20] [21] [22] [23].

The output is goods and services. In 1937, Adam Smith expressed his idea of the specialization of the production system and the division of labor would realize 3 things, namely developing employee skills, shortening time and creating various tools or machines that make work activities easier.

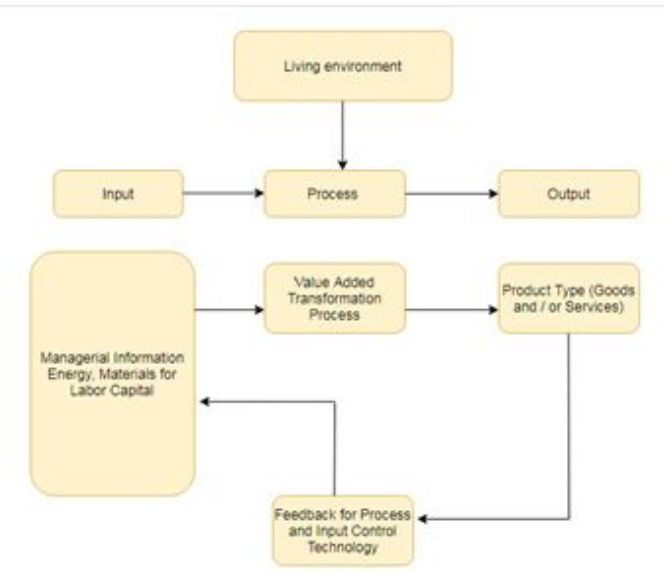

Figure 4. Production System

Regarding Figure 4, describes the operational management picture that is inputting and outputting a process of change in the production system, which goes through the stages of input - process - output. The process of change in each industry varies the type of industry, namely alter, transportation, shop and inspection.

The making of batik crafts goes through several stages or processes. The first stage of making batik is cutting the fabric into several sections with a predetermined size. At the time of fabric purchase, the size of the fabric is only one roll of fabric which is then cut into 18-20 pieces of fabric. Usually the fabric cutting part is done by those who are skilled in dividing the fabric The right size so that there is no disposal of cloth left over because of the cut. After the fabric cutting process is completed, the second step, which is arrangement or can be called setup, is making fabric pores. 


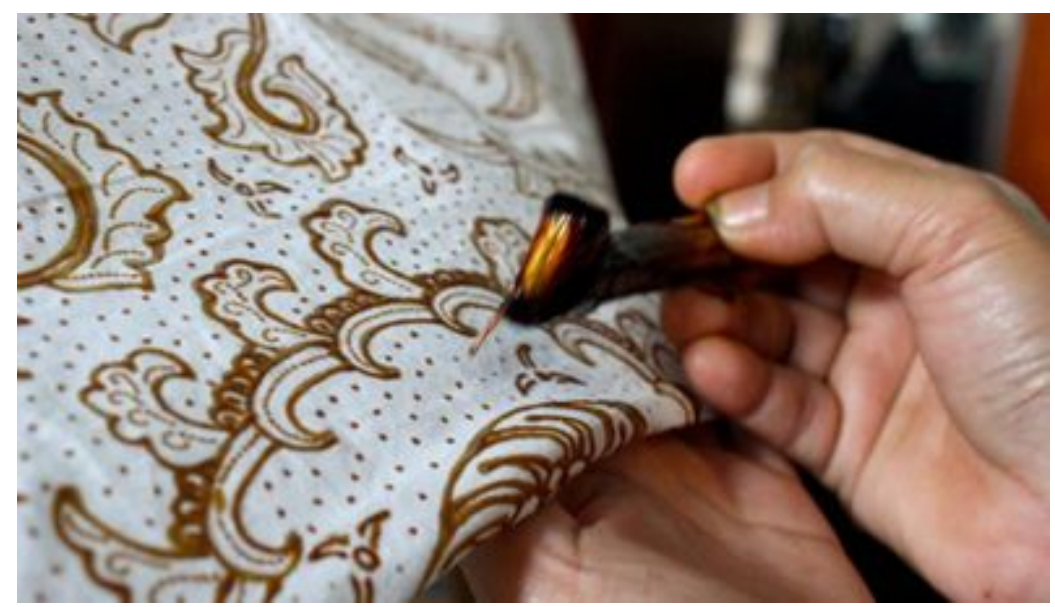

Figure 5. Night pouring into a pattern

The next stage of making batik crafts is making patterns on the fabric. When making patterns on fabric, pattern making is done by those who are experts and have high creativity, the batik motif that will be made. If you have made the basic pattern, the next step is to continue the pattern of the image on the fabric until it is finished. The pattern making stage is usually done by skilled craftsmen, because skilled craftsmen certainly have interesting batik pattern ideas.

After the cloth is filled with patterns, the next step is to do the pattern thickening on the fabric or commonly called slamming. Usually this method of slamming by applying wax (night) to the fabric using canting so that the fabric depiction can be in accordance with batik patterns, using wax (night) is not just anyone can do only those who are professional, because tonight must be on a small stove that lights, then the nature of wax (wax) has a hot nature and if exposed to the skin will cause blisters or burns. Usually the results of a good and interesting listing will produce a high selling price.

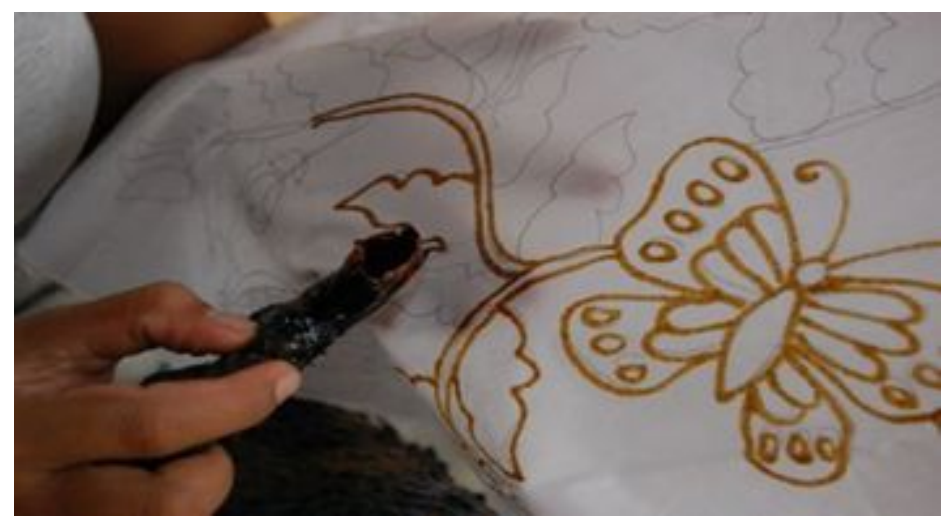

Figure 6. Stage of slamming on the pattern

The workmanship of the patterns, as well as giving nights to batik are usually done at the home of their respective craftsmen. The working time is influenced by the spirit of the craftsmen themselves. If the craftsmen have high enthusiasm, the craftsmen will be diligent in doing their work so that batik work can be done in 3-4 days. The next stage is the colet stage which is the stage of giving color to the pattern. The coloring used may use natural 
colors or colors derived from chemicals. Many natural dyes are obtained from the local environment. For example, the green color can come from pandan leaves or suji leaves, the blue color comes from tarum flowers and the yellow color comes from turmeric and many more natural ingredients that can be used as coloring for batik crafts.

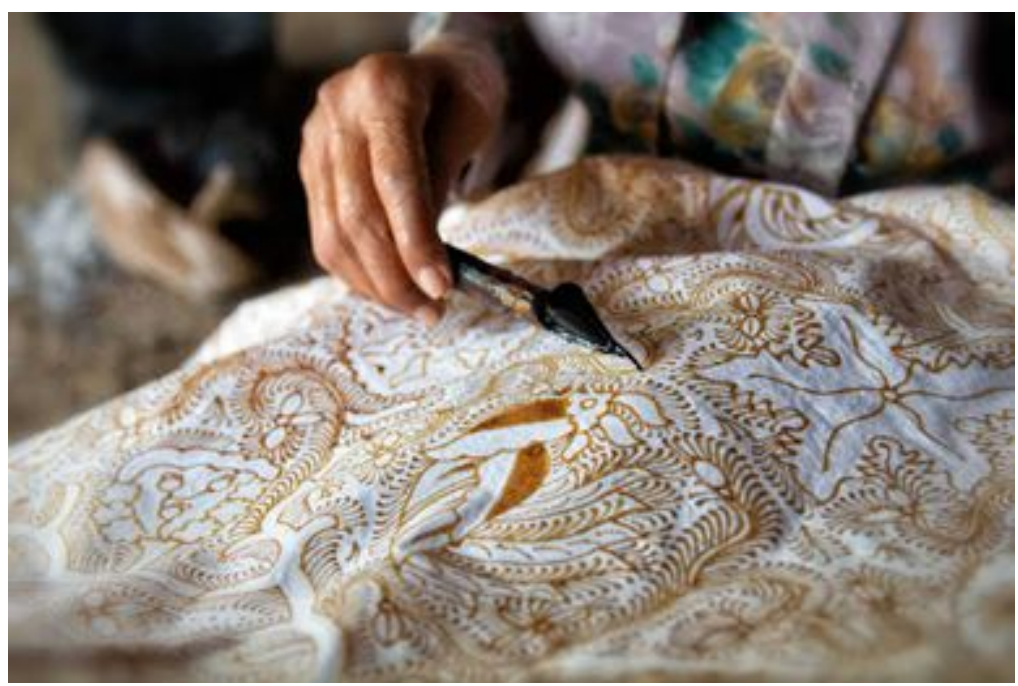

Figure 7. Closing Phase of the base color

The last stage or closing phase which is commonly called the blocking or walling technique is closing the pattern with the color of the wax of the night. The night candle aims to protect the pattern so that the colors given during the colet stage are not mixed during the basic coloring stage. The construction budget depends on the number or limitations of the pattern, while the processing time is the craftsman. If the craftsmen have the enthusiasm to do it quickly, then in one day the craftsman can get two batik, the results obtained are also quite large. After the closing step, the next stage is the coloring stage, where the coloring is done after the installation stage is finished by the craftsman. Therefore batik cloth has a high meaning and price.

\section{Conclusion}

The first appearance of Sumenep batik was in 1269 in the Sumenep Palace family in the era of the first kingdom. Due to the lack of interest of the Keraton family in batik crafts, so that batik crafts are almost extinct. But at that time there was one of the craftsmen where the craftsman was guiding the women in the village to learn to make batik crafts. The stages of batik work in Sumenep Regency are still fairly traditional, each stage of batik making is done by each craftsman. Working on batik crafts is a part-time job done from generation to generation until batik craftsmen have minimal creativity. The lack of interest and creativity of the new generation makes the lack of batik craftsmen. Batik craftsmanship is currently still using manual techniques and has not fully utilized existing technology. And the lack of creativity of the new generation in making designs that are in line with market tastes, as well as the efforts made by local governments to only provide assistance to the business sector and partly to craftsmen, are not very inclusive to develop batik as a source of economic factors. In government, the role of the Sumenep Regional Government in implementing regional authority is less than optimal in creating regulations that support the development of the batik craft industry in Sumenep Regency. So the typical batik handicrafts of Sumenep are not too well-known due to their government being less supportive of these batik crafts. 


\section{References}

[1] E. Herlina, D. Syarifudin, and N. Mulyatini, "Knowledge transfer in the context of spatial creative economy to reduce rural poverty in ciamis district," J. Ecology of Management Science., vol. 5, no. April, pp. 273-282, 2018.

[2] IN Lodra, N. Mariasa, and W. Hardayaningrum, "Identification of Madura Klampar Written Batik Motifs in Copyright Protection," TEAM Proceeding, vol. 2, p. 1, 2017, doi: 10.23887 / team.vol2.2017.150.

[3] K. Batik, D. Staining, and A. Alamsyah, "Endogamy: Scientific Journal of Anthropological Studies."

[4] I. Cahyadi, "Developing A Model with Dematel, Anp, Topsis Approaches for Marketing Strategy Selection in Batik Madura Industry," Matrix J. Management, Strateg. Business and Entrepreneurship, vol. 14, no. 1, p. 20, 2019, doi: 10.24843 / matrix: jmbk.2020.v14.i01.p03.

[5] A. Atsar, "About Copyright," J. Law Reform Program. Stud Masters in Law, vol. 13, no. 2, p. 284, 2017.

[6] MF Benyamin and AR Prasetia, "Glokalizer: Urban Aesthetic Concepts as Creative Strategies for Batik Artwork in Maintaining Existence on the World Stage," Semin. Nas. Strategic. Indonesia. Kreat. Facing the ASEAN Econ. Community 2015, pp. 397-409, 2015, doi: 10,13140 / RG.2.1.2512.6489.

[7] F. Kurniawan, A. Soeprijanto, HL Guntur, M. Wardhana, I. Abadi, and S. Sayyida, "Mapping the Potential of Halal Tourism in Sumenep Regency, East Java, Indonesia," Dinar J. Ekon. and money. Islam, vol. 5, no. 2, 2019, doi: 10.21107 / dinar.v5i2.5002.

[8] U. Rahardja, T. Hariguna, Q. Aini, and S. Santoso, "Understanding behavioral intentions of using mobile apps in transportation: An empirical study," Int. J. Adv. Trends Comput. Sci Eng., vol. 8, no. 1.5 Special Issues, pp. 258-263, 2019, doi: 10.30534 / ijatcse / 2019 / 4581.52019.

[9] EDI Suyikno, "The development of traditional batik crafts in the burnt village of Juwana Subdistrict, Pati Regency in 1977-2002," 2017.

[10] P. Covid-, D. Amany, and A. Desire, "Gamification-based Interactive Learning to Support the WFH Program at the moment," pp. 48-55.

[11] U. Rahardja, A. Singh Bist, M. Hardini, Q. Aini, and EP Harahap, "Authentication of Covid-19 Patient Certification with Blockchain Protocol," Int. J. Adv. Sci Technol., vol. 29, no. 8s, pp. 4015-4024, 2020.

[12] Cl Burhanuddin and MN Abdi, "AkMen AkMen," Crisis, Glob Threat. Econ. Impact, From, vol. 17, pp. 710-718, 2020.

[13] MZ Arifin, "Basic Concepts of Regional Autonomy in Indonesia after Reformation," J. Chem. Inf. Model., vol. 53, no. 9, pp. 1689-1699, 2013, doi: 10.1017 / CBO9781107415324.004.

[14] B. Kurniawan, "Analysis of the Leading Economic Sector in Kerinci Regency, Jambi Province," El-jizya J. Ekon. Islam, vol. 4, no. 1, pp. 1-26, 2017, doi: 10.24090 / ej.v4i1.2016.pp1-26. 
[15] T. Borshalina, "Marketing Strategy and the Development of Trusmi Batik in the Regency of Cirebon which Used Natural Coloring Matters," Procedia - Soc. Behav Sci, vol. 169, no. August 2014, pp. 217-226, 2015, doi: 10.1016 / j.sbspro.2015.01.305.

[16] I. Putra and I. Dana, "The Effect of Profitability, Leverage, Liquidity and Company Size on Pharmaceutical Company Stock Returns in Bei," Manaj E-Journal. Univ. Udayana, vol. 5, no. 11, p. 249101, 2016.

[17] A. Kamil, "Indonesian Creative Industries: Approach to Industrial Performance Analysis," Media Trend, vol. 10, no. 2, pp. 207-225, 2015.

[18] HT Widodo, "The Role and Benefits of Social Capital in Increasing the Work Effectiveness of Employees of the Micro and Small Business Sector in the Center for Handbags and Suitcases Tanggulangin Sidoarjo," JBMP (Journal of Business, Management and Banking), vol. 2, no. 1, p. 01, 2016, doi: 10.21070 / jbmp.v2i1.911.

[19] R. Aulia, A. Sururi, and S. Sukendar, "Effectiveness of Featured Products of Rural Areas Program (Prukades) in Improving the Economy of Teluk Village Community Pandeglang Regency," ADI J. Recent Innov., vol. 2, no. 1, pp. 204-211, 2020, doi: 10.34306 / ajri.v2i1.37.

[20] E. Prasetyowati, "Application of Determining Principal Prices for Madura Batik Production Using Activity Based Costing Methods and Linear Regression Analysis," JUTI J. IIm. Teknol. Inf., vol. 16, no. 1, p. 48, 2018, doi: 10.12962 / j24068535.v16i1.a690.

[21] Hariguna, Taqwa, Muhamad Yusup, and Agung Priyadi. 2019. "The Transaction Optimization Of Color Print Sales Through E-Commerce Website Based On Yii Framework On Higher Education." Aptisi Transactions On Technopreneurship (ATT) 1(1): $1-10$.

[22] Santoso, Sugeng, Josch Kauf, and Nabila Cynthia Aristo. 2019. "The Information System of Name Card Sales Based on Digital Marketing to Improve Creativepreneur on College E-Commerce Website." Aptisi Transactions On Technopreneurship (ATT) 1(1): 64-72.

[23] Sunarya, Po Abas, Doucette David Bernard, and Dian Maharani Damanik. 2019. "Viewboard Implementation Based on Javascript Charts as a Media for Submitting Sales Information on a Green E-Commerce Website Light Cafe." Aptisi Transactions On Technopreneurship (ATT) 1(1): 11-19.

[24] Zarlis, Muhammad, Eka Purnama Harahap, and Lina Naelal Husna. 2019. "Test Appraisal System Application Based on YII Framework as Media Input Student Value Final Project and Thesis Session at Higher Education." Aptisi Transactions On Technopreneurship (ATT) 1(1): 73-81. 